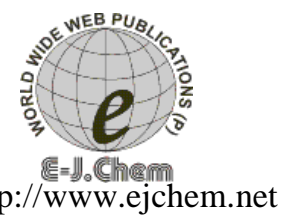

ISSN: 0973-4945; CODEN ECJHAO

E-Journal of Chemistry

2012, 9(2), 772-779

\title{
Synthesis, Crystal Structure and Computational Studies of 1-Phenylpiperazin-1, 4-Diium Nitrate Monohydrate
}

\author{
H. MAROUANI ${ }^{{ }^{*}}$, N. RAOUAFI ${ }^{\#}$, S. TOUMI AKRICHE ${ }^{\S}$, \\ S. S. AL-DEYAB and M. RZAIGUI ${ }^{\S}$ \\ ${ }^{\S}$ Laboratoire de Chimie des Matériaux \\ Faculté des Sciences de Bizerte, 7021 Zarzouna, Tunisie \\ \# Laboratoire de Chimie Analytique et d'Electrochimie \\ Département de Chimie, Faculté des Sciences de Tunis, Université Tunis El-Manar \\ Rue Béchir Salem Belkhiria, 2092 Tunis El-Manar, Tunisia \\ Petrochemical Research Chair, \\ College of Science, King Saud University, Riadh, Saudi Arabia
}

Houda.marouani@fsb.rnu.tn

Received 17 September 2011; Accepted 13 November 2011

\begin{abstract}
Reaction of phenylpiperazine and nitric acid yields the new organicinorganic hybrid material of phenylpiperazinium $\left(\mathrm{C}_{10} \mathrm{H}_{16} \mathrm{~N}_{2}\right)\left(\mathrm{NO}_{3}\right)_{2} \cdot \mathrm{H}_{2} \mathrm{O}$, (I). To understand the interaction between components of this salt, single crystal structure and computational studies are performed and reported. X-ray diffraction analysis was employed for the structural characterization. Computational methods were exploited for ground state structure determination and HOMO-LUMO calculations were determined. Detailed studies on ground state structure determinations as well as Electrostatic Potential Surface maps have been estimated by applying second-order MøllerPlesset (MP2) perturbation theory.
\end{abstract}

Key words: X-ray diffraction, Solid state PM6 method, Second-order Møller-Plesset (MP2), Mapped electrostatic potential surfaces, HOMO-LUMO.

\section{Introduction}

Phenylpiperazine and its derivatives have been intensively investigated recently due to their attractive pharmacological, autonomic and cardiovascular properties ${ }^{1-3}$. Some phenylpiperazinium derivatives, for instance, are a well known nicotinic agonist for example, DMPP, $N^{1}$-dimethyl- $N^{4}$-phenylpiperazinium iodide which is reported to bind the nicotinic receptor against $\left[{ }^{3} \mathrm{H}\right]$-cytisine in rat cerebral cortex ${ }^{4}$. For these reasons, we continue our previous study of these species ${ }^{5-6}$. In this paper, we report the synthesis and the structural study of $\left(\mathrm{C}_{10} \mathrm{H}_{16} \mathrm{~N}_{2}\right)\left(\mathrm{NO}_{3}\right)_{2} \cdot \mathrm{H}_{2} \mathrm{O}$, (I). The X-ray diffraction data have been compared to the results of 
theoretical calculations in the solid-state using the PM6-DH2 semi-empirical method ${ }^{7}$. More accurate investigations in gas phase by applying the second-order Møller-Plesset (MP2) perturbation theory ${ }^{8}$ and Natural Bond Orbital (NBO) analysis ${ }^{9}$ have been done in order to access to the mapped electrostatic potential surface and to the atomic charges of the compound.

\section{Experimental}

Single crystals of $\left(\mathrm{C}_{10} \mathrm{H}_{16} \mathrm{~N}_{2}\right)\left(\mathrm{NO}_{3}\right)_{2} \cdot \mathrm{H}_{2} \mathrm{O}$ were prepared at room temperature from an aqueous mixture of $1 \mathrm{mmol}$ of phenylpiperazine (Acros, $\mathrm{d}=1.062$ ) and $30 \mathrm{~mL}$ of nitric acid $(\mathrm{d}=1.38)$ solution $(0.1 \mathrm{M})$.

Schematically, the reaction can be written as follows:

$$
\mathrm{C}_{10} \mathrm{H}_{14} \mathrm{~N}_{2}+2 \mathrm{HNO}_{3}+\mathrm{H}_{2} \mathrm{O} \rightarrow\left(\mathrm{C}_{10} \mathrm{H}_{16} \mathrm{~N}_{2}\right)\left(\mathrm{NO}_{3}\right)_{2} \cdot \mathrm{H}_{2} \mathrm{O}
$$

This mixture was stirred during $15 \mathrm{~min}$ then slowly evaporated at room temperature until the formation of good quality brown prismatic single crystals.

\section{Crystallographic studies}

The single crystal X-ray analysis data were collected on the Enraf-Nonius CAD4 diffractometer using the $\mathrm{Ag} \mathrm{K \alpha}$ radiation $(\lambda=0.56087 \AA)$ at the temperature of $298 \mathrm{~K}$. The structure was solved by direct method using the program SHLXS $97^{10}$ in the WinGX package $^{11}$ and refined by full-matrix least squares method SHLXL97 ${ }^{10}$. All non-hydrogen atoms were refined isotropically and then anisotropically by full matrix least square method. All hydrogen atoms were placed geometrically and treated as riding. Crystallographic data for (I) is summarized in Table 1. An ORTEP ${ }^{12}$ drawing of the molecular structure is shown in Figure 1. Crystallographic data (CIF) for the structure reported in this paper have been deposited in the Cambridge Crystallographic Data centre as supplementary materials No CCDC 828743. Copies of the data can be obtained, free of charge, from the Cambridge Crystallographic Data Centre via www.ccdc.cam.ac.uk/data_request/cif.

\section{Theoretical calculations}

Solid-state semi-empirical calculations for the crystal of the title compound was carried out and HOMO-LUMO energy gap were determined by the PM6-DH2 ${ }^{7}$ method using the MOPAC2009 package ${ }^{13}$. Quantum calculations for a single molecule of (I) in gas phase have been performed by applying the second-order Møller-Plesset (MP2) perturbation theory ${ }^{8}$ coupled to $6-31 \mathrm{G}^{++}$basis set and Natural Bond Orbital (NBO) analysis ${ }^{9}$ by means of Gaussian $03 \mathrm{~W}$ package ${ }^{14}$. Visualization of results and the mapped electrostatic potential surface calculations were performed with the GaussView 4.1.2 package $^{15}$.

\section{Results and Discussion}

\section{Crystal structure}

The asymmetric unit of (I) consists of two nitrate anions, one 1-phenylpiperazine-1,4-diium cation and one water molecule (Figure 1). In this structure, the nitrate anions are associated together in pair through bifurcated hydrogen bonds generated by water molecules forming four-membred rings which may be described as $R_{1}{ }^{2}(4)$ motif in the graph-set notation ${ }^{16}$. These clusters of formula $\left[\left(\mathrm{NO}_{3}\right)_{2} \cdot \mathrm{H}_{2} \mathrm{O}\right]^{2-}$ are interconnected via organic cations via a set of $\mathrm{N}-\mathrm{H}$...O and $\mathrm{C}-\mathrm{H}$...O hydrogen bonds as shown in Figure 2 with donor-acceptor distances varying between 2.743 (3) and 3.415 (6) Å (Table 2). 
Table 1. Crystal data and experimental parameters used for the intensity measurements.

\begin{tabular}{|c|c|}
\hline Empirical formula & $\mathrm{C}_{10} \mathrm{H}_{18} \mathrm{O}_{7} \mathrm{~N}_{4}$ \\
\hline Formula weight & 306.28 \\
\hline $\mathrm{T}(\mathrm{K})$ & 293 \\
\hline Wavelength $(\AA)$ & 0.5608 \\
\hline Crystal system & monoclinic \\
\hline Space group & $\mathrm{P} 2{ }_{1} / \mathrm{c}$ \\
\hline $\mathrm{a}(\AA)$ & $9.299(3)$ \\
\hline $\mathrm{b}(\AA)$ & $9.1808(10)$ \\
\hline$c(\AA)$ & $18.565(6)$ \\
\hline$\beta\left(^{\circ}\right)$ & $117.67(3)$ \\
\hline $\mathrm{Z}$ & 4 \\
\hline $\mathrm{V}\left(\AA^{3}\right)$ & $1403.6(7)$ \\
\hline$\rho_{\text {cal. }}, \mathrm{g} \mathrm{cm}^{-3}$ & 1.449 \\
\hline $\mathrm{F}(000)$ & 648 \\
\hline$\mu(\operatorname{AgK} \alpha)$ & $0.074 \mathrm{~mm}^{-1}$ \\
\hline Crystal size $[\mathrm{mm}]$ & $0.29 \times 0.25 \times 0.17$ \\
\hline Collected unique reflections & Collected unique reflections \\
\hline \multicolumn{2}{|c|}{ 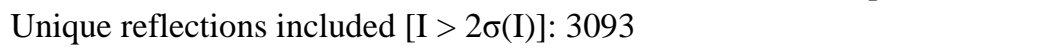 } \\
\hline $\mathrm{R}\left[\mathrm{F}^{2}>2 \sigma\left(\mathrm{F}^{2}\right)\right]$ & 0.084 \\
\hline$w R\left(F^{2}\right)$ & 0.251 \\
\hline$\Delta \rho_{\min }, \Delta \rho_{\max }$ & $-0.29,0.51$ e $\AA^{3}$ \\
\hline Goodness-of-fit & 0.88 \\
\hline
\end{tabular}

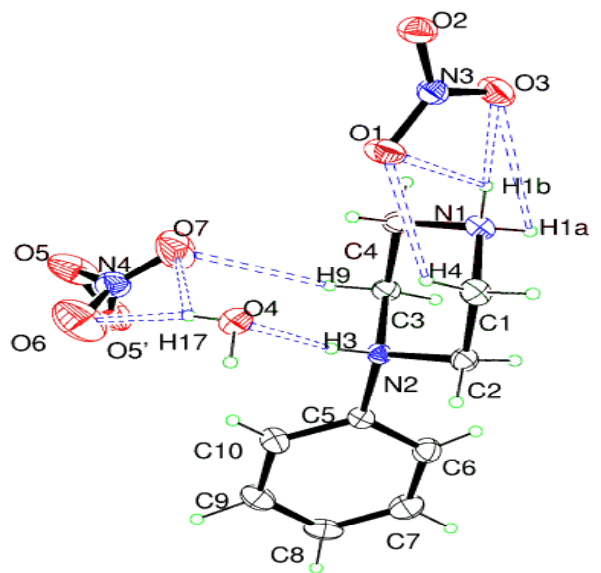

Figure 1. ORTEP drawing of $\left(\mathrm{C}_{10} \mathrm{H}_{16} \mathrm{~N}_{2}\right)$ $\left(\mathrm{NO}_{3}\right)_{2} \cdot \mathrm{H}_{2} \mathrm{O}$ with the atom-labeling scheme. Displacement ellipsoids are drawn at the $30 \%$ probability level. $\mathrm{H}$ atoms are represented as small spheres of arbitrary radii.

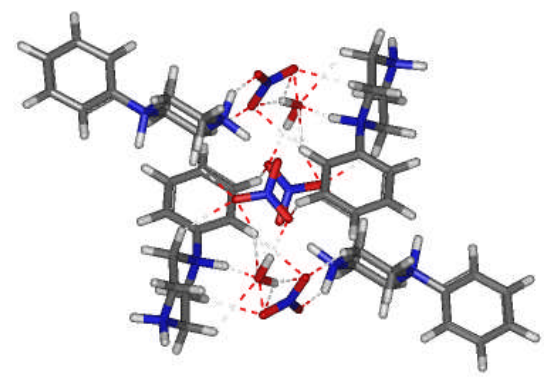

Figure 2. X-ray Crystal packing of (I). 
Table 2. Hydrogen-bond geometry $\left(\AA{ }^{\circ}{ }^{\circ}\right)$.

\begin{tabular}{ccccc}
\hline$D-\mathrm{H} \cdots A$ & $D-\mathrm{H}$ & $\mathrm{H} \cdots A$ & $D \cdots A$ & $D-\mathrm{H} \cdots A$ \\
\hline $\mathrm{O} 4-\mathrm{H} 17 \cdots \mathrm{O} 6$ & $0.859(10)$ & $2.123(13)$ & $2.972(5)$ & $170(3)$ \\
$\mathrm{O} 4-\mathrm{H} 17 \cdots \mathrm{O} 7$ & $0.859(10)$ & $2.24(3)$ & $2.875(5)$ & $130(3)$ \\
$\mathrm{O} 4-\mathrm{H} 18 \cdots \mathrm{O} 2^{\mathrm{i}}$ & $0.855(10)$ & $2.030(18)$ & $2.863(3)$ & $165(5)$ \\
$\mathrm{O} 4-\mathrm{H} 18 \cdots \mathrm{O} 1^{\mathrm{i}}$ & $0.855(10)$ & $2.46(4)$ & $3.158(4)$ & $139(5)$ \\
$\mathrm{N} 1-\mathrm{H} 1 \mathrm{~B} \cdots \mathrm{O} 3$ & 0.90 & 1.92 & $2.818(4)$ & 178 \\
$\mathrm{~N} 1-\mathrm{H} 1 \mathrm{~B} \cdots \mathrm{O} 1$ & 0.90 & 2.52 & $3.123(4)$ & 125 \\
$\mathrm{~N} 1-\mathrm{H} 1 \mathrm{~A} \cdots \mathrm{O} 5^{\text {ii }}$ & 0.90 & 2.23 & $2.937(8)$ & 135 \\
$\mathrm{~N} 1-\mathrm{H} 1 \mathrm{~A} \cdots \mathrm{O} 3^{\mathrm{iii}}$ & 0.90 & 2.22 & $3.033(4)$ & 150 \\
$\mathrm{~N} 1-\mathrm{H} 1 \mathrm{~A} \cdots 5^{\text {ii }}$ & 0.90 & 2.34 & $2.818(11)$ & 113 \\
$\mathrm{~N} 1-\mathrm{H} 1 \mathrm{~A} \cdots \mathrm{O} 2^{\text {iii }}$ & 0.90 & 2.63 & $3.179(4)$ & 121 \\
$\mathrm{~N} 2-\mathrm{H} 3 \cdots \mathrm{O} 4$ & $0.83(3)$ & $1.94(3)$ & $2.743(3)$ & $164(2)$ \\
$\mathrm{C} 1-\mathrm{H} 4 \cdots \mathrm{O} 1$ & $0.92(3)$ & $2.54(3)$ & $3.198(5)$ & $129(3)$ \\
$\mathrm{C} 1-\mathrm{H} 5 \cdots \mathrm{O} 6^{\mathrm{ii}}$ & $0.89(3)$ & $2.56(3)$ & $3.415(6)$ & $163(3)$ \\
$\mathrm{C} 3-\mathrm{H} 8 \cdots \mathrm{O} 3^{\text {iii }}$ & $0.95(3)$ & $2.57(3)$ & $3.295(4)$ & $133(2)$ \\
$\mathrm{C} 3-\mathrm{H} 9 \cdots \mathrm{O} 7$ & $0.94(4)$ & $2.48(4)$ & $3.258(5)$ & $139(3)$ \\
$\mathrm{C} 3-\mathrm{H} 9 \cdots \mathrm{Cg}{ }^{\text {iv }}$ & $0,95(3)$ & $3,07(7)$ & $3,553(10)$ & 114 \\
\hline
\end{tabular}

Symmetry Codes : (i) $-x+1, y+1 / 2,-z+1 / 2$; (ii) $x,-y+3 / 2, z+1 / 2$; (iii) $-x, y+1 / 2,-z+1 / 2 ;($ iv $)-x+1$, $y+2,-z$.

Comparison of the present structure with related phenylpiperazinium salts ${ }^{5,6}$, shows that the inorganic moieties have distinct features. One can distinguish the formation of $\left(\mathrm{H}_{2} \mathrm{PO}_{4}{ }^{-}\right)_{\mathrm{n}}$ and $\left(\mathrm{HSO}_{4}^{-}\right)_{\mathrm{n}}$ chains parallel respectively to a-direction in the case of $\left(\mathrm{C}_{10} \mathrm{H}_{15} \mathrm{~N}_{2}\right) \mathrm{H}_{2} \mathrm{PO}_{4}{ }^{5}$ and c-direction in the case of $\left(\mathrm{C}_{10} \mathrm{H}_{16} \mathrm{~N}_{2}\right)\left(\mathrm{HSO}_{4}\right)_{2}{ }^{6}$. In each structural variety, the anions and the phenylpiperazinium cations are linked together by a set of $\mathrm{H}$-bonds in addition to electrostatic and van der Waals interactions, generating a threedimensional network.

The aromatic ring of the organic cation is essentially planar with an rms deviation of $0.000311 \AA$ while the diprotonated piperazine ring adopts a chair conformation, with puckering parameters ${ }^{17}: Q=0.5756(34) \AA, \theta=177.64(35)^{\circ}$ and $\varphi=-37(9)^{\circ}$. The interatomic bond lengths and angles in (I) do not show significant deviation from those reported in related 1-phenylpiperazine-1,4-diium salts ${ }^{5-6,18}$.

The inter-planar distance between nearby phenyl rings is in the vicinity of $5.552 \AA$, which is longer than $3.80 \AA$, value required for the formation of $\pi-\pi$ interactions ${ }^{19}$. Nevertheless, we notice the presence of the C-H... $\pi$ interaction between these organic entities $^{20}$. This kind of interaction contributes with the hydrogen bonds and the electrostatic interactions to the cohesion and stability of the network of the described crystal structure.

\section{PM6 solid state structure calculations}

Recently, the new semi-empirical method PM6 (parameterized model 6) was introduced ${ }^{21}$, which is superior to other semi-empirical QM methods in various aspects. Crystal structure packing of the title compound (I) were fully optimized using the parameterized model 6 (PM6-DH2) implement in MOPAC2009 ${ }^{13}$ and compared with those from X-ray diffraction data. Theoretical investigation on the structure reveals that the calculated cell parameters are close to experimental data as can be seen in Table 3. This result shows that the $\mathrm{O}-\mathrm{H}$... $\mathrm{O}$ interactions between the two independent $\mathrm{NO}_{3}{ }^{-}$anions with the water molecule lead to the formation of clusters $\left[\left(\mathrm{NO}_{3}\right)_{2} \cdot \mathrm{H}_{2} \mathrm{O}\right]^{2-}$ as evidenced by X-ray analysis. The water molecules in these clusters are strongly attached to the phenylpiperazinium cations with calculated N...O 
distance equal to $2,648 \AA$ which is only about $10 \%$ shorter than the experimental value $\left(\mathrm{d}(\mathrm{N} . . . \mathrm{O})_{\exp }=2.743\right.$ (3) $\AA$ (Table. 2).

Table 3. Theoretically computed structural and energy parameters.

\begin{tabular}{cc}
\hline Parameters & Parameterized model (PM6-DH2) \\
\hline \multicolumn{1}{c}{ Calculated cell parameters } \\
$\mathrm{a}, \mathrm{b}, \mathrm{c}(\AA)$ & $9.187,9.074,18.360$ \\
$\alpha, \beta, \gamma\left({ }^{\circ}\right)$ & $91.22,116.23,89.64$ \\
$\mathrm{~V}\left(\AA^{3}\right)$ & 1372.7 \\
$d_{\text {cal }}\left(\mathrm{Mg} \mathrm{m}^{-3}\right)$ & 1.482 \\
HOMO $(\mathrm{eV})$ & -10.305 \\
LUMO $(\mathrm{eV})$ & -1.592 \\
Energy gap $(\mathrm{eV})$ & 8.713 \\
\hline
\end{tabular}

\section{Mapped electrostatic potential surfaces and NBO charge distribution}

In the last decades, calculation of electrostatic potential maps becomes a useful tool for visualizing charge distribution in ions and neutral molecules ${ }^{22}$. The NBO natural charges distribution obtained from theoretical study for neutral phenylpiperazine shows that the N1 and $\mathrm{N} 2$ nitrogen atoms exhibit a substantional negative charge, which are donor atoms. The charge values on the nitrogen atoms are of -0.52 and -0.72 e respectively for the $\mathrm{N} 1$ and $\mathrm{N} 2$ nitrogen atoms. This large charge density indicates that the protonation of these atoms sites are possible. These atoms may also play an important role in the biological activity of phenylpiperazine derivatives ${ }^{23}$. However, both nitrogen atoms can react as electron donors with Lewis acid because they have electron pairs which well explain their reactivity with $\mathrm{H}^{+}$ protons.

In the compound (I), the presence of two positive charges on the nitrogen affects significantly the electronic density of the cation. The NBO natural charges distribution obtained from theoretical study for cation of compound (I) shows that the charges on the nitrogen atoms are of +0.46 and +0.64 e respectively for $\mathrm{NH}^{+}$and $\mathrm{NH}_{2}^{+}$groups meaning that the complement of the unit charge is delocalized over the aromatic cycle and the other cycle. Effectively, the hydrogen atom on $\mathrm{NH}^{+}$group bears a positive charge of $+0.48 \mathrm{e}$, while the two others hydrogen atoms on the $\mathrm{NH}_{2}^{+}$group shared almost equally the positive charge in fact they have +0.49 and +0.51 e.

All the carbon atoms of the aromatic cycle are negatively charged and bearing a mean charge -0.20 e expects the one directly linked to the nitrogen which is positively charged of $0.08 \mathrm{e}$. The piperazine carbon atoms are negatively charged with mean charge of $-0.30 \mathrm{e}$ and all the hydrogen bears +0.3 e of charge. Moreover, electrostatic potential surfaces have been determined from the total electron density calculated MP2 ab-initio and mapped with electrostatic potential at 0.002 a.u. The charge distributions for the isolated cation and for the organic cation-two nitrates anions are given in Figure 3.

\section{HOMO-LUMO analysis}

Molecular orbital and their properties are very useful for physicists and chemists. In particular, the highest occupied molecular orbital (HOMO) and the lowest unoccupied molecular orbital (LUMO) and their energy gap reflect the chemical activity of the molecule 24-25. Recently the energy gap between HOMO and LUMO has been used to prove the bioactivity from intramolecular charge transfer ${ }^{26-28}$. The HOMO-LUMO energy gap for I was calculated according to PM6-DH2 ${ }^{7}$ procedures implemented in MOPAC2009 package $^{13}$ and 
the HOMO and LUMO orbitals drawing are depicted in Figure 4. The found LUMOHOMO energy gap of (I) value is $8.713 \mathrm{eV}$. This value, which is relatively large, indicates a high stability and high chemical hardness of compound $(\mathrm{I})^{29}$.

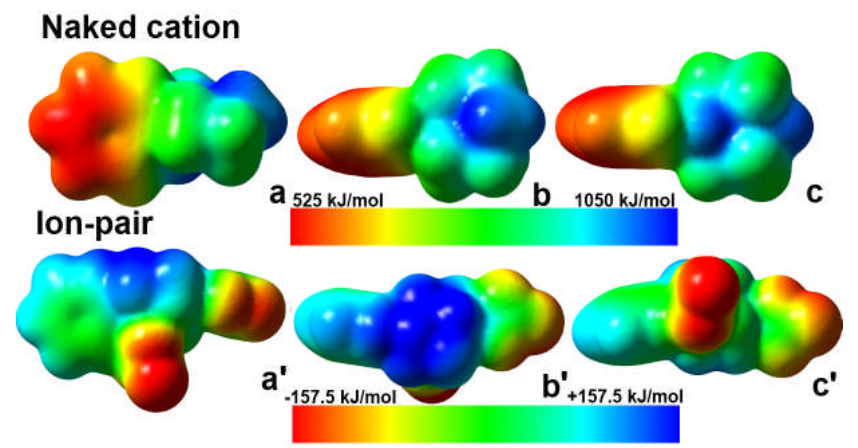

Figure 3. Calculated electrostatic potentials surfaces generated at an isodensity of 0.002 a.u. (a), (b) and (c) are different views of the isolated cation $\left(\mathrm{C}_{10} \mathrm{H}_{16} \mathrm{~N}_{2}\right)^{2+}$ showing the charges distribution over the molecule. Electrostatic potential surface energies range from +525.1 (red) to +1050.2 (blue) $\mathrm{kJmol}^{-1}$. Views (a'), (b') and (c') are for the phenylpiperazinium cation-two nitrate anions revealing the charge distribution at the surface of the compound. Water molecule was not considered in calculation in order to get better viewer of the charge repartition at the surface. Electrostatic potential surface energies range from -157.7 (red) to +157.7 (blue) $\mathrm{kJmol}^{-1}$. (For interpretation of the references to color in this figure legend, the reader is referred to the web version of this article).

The HOMO are localized mainly in the nitrate anion and $\mathrm{NH}_{2}^{+}$and $\mathrm{CH}_{2}$ moieties whereas the LUMO of $\pi$ nature are mostly located on the phenyl ring. LUMO as an electron acceptor represents the ability to obtain an electron; HOMO represents the ability to donate an electron. The HOMO-LUMO transition implies an electron density transfer to the phenyl ring from $\mathrm{NO}_{3}{ }^{-}$anion. The visualization of HOMO-LUMO gap is shown in Figure 4.
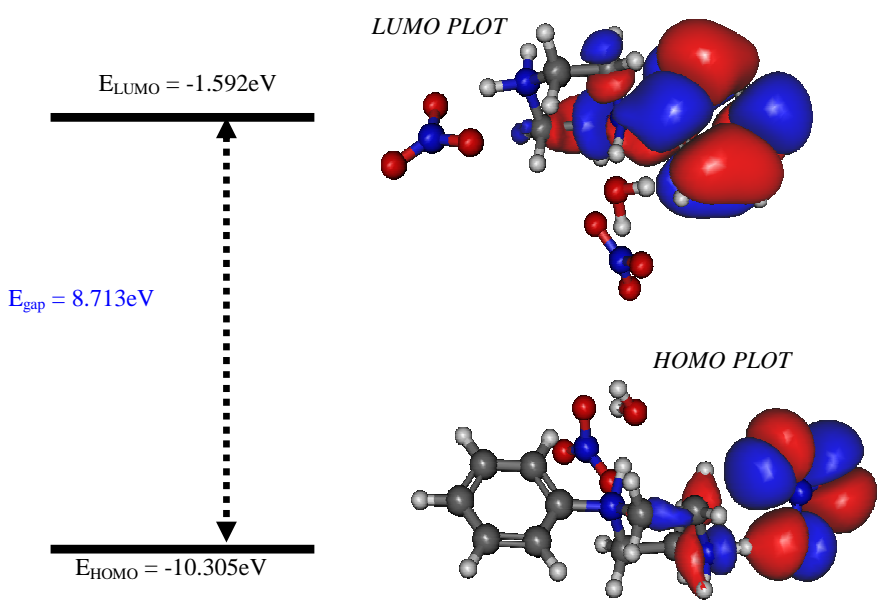

Figure 4. Molecular orbital surfaces and energy level for the HOMO, LUMO and the energy gap of (I) computed by PM6-DH2 method. 


\section{Conclusion}

The novel compound $\left(\mathrm{C}_{10} \mathrm{H}_{16} \mathrm{~N}_{2}\right)\left(\mathrm{NO}_{3}\right)_{2} \cdot \mathrm{H}_{2} \mathrm{O}(\mathrm{I})$, was investigated by $\mathrm{x}$-ray diffraction and different theoretical methods. In effects, the crystal structure study has been well compared by theoretical calculations with a PM6-DH2 semi-empirical method. The HOMO and LUMO energies are determined. The HOMO-LUMO energy gap value implies that compound (I) is quite stable in terms of energy and has a high chemical hardness. Natural Bond Orbital (NBO) analysis indicates the presence of donor-acceptor centers in the investigated compound and the mapped electrostatic potential surfaces calculated from the total electron density, obtained by applying the second-order-Møller-Plesset (MP2) perturbation theory, reveal a high electron density around the oxygen atoms of nitrate anions explaining the formation of electrostatic and $H$-bonds interactions with the two protonated nitrogen atoms of the phenylpiperazinium cation.

\section{Acknowledgment}

The authors want to thank Dr. James J. P. Stewart for allowing us to use his MOPAC 2009 (Version: $10.341 \mathrm{~W}$ ) and we thank the Ministry of Higher Education and Technology for laboratory funding.

\section{References}

1. Conrado D J, Verli H, Neves G, Fraga C A, Barreiro E J, Rates S M and Dalla-Costa T, Pharm Pharmacol., 2008, 60, 699.

2. Neves G, Fenner R, Heckler A P, Viana A F, Tasso L, Menegatti R, Fraga C A M, Barreiro E J, Dalla-Costa T, Rates S M and Braz K, J Med Biol Res., 2003, 36, 625.

3. Cohen M R, Hinsch E, Palkoski Z, Vergona R, Urbano S and Sztokalo J, J Pharmcol Exp Ther., 1982, 223, 110.

4. Romanelli M N, Manetti D, Scapecchi S, Borea P A, Dei S and Bartolini A, J Med Chem., 2001, 44, 3946.

5. Essid M, Marouani H, Rzaigui M and Al-Deyab S S, Acta Cryst., 2010, E66, o2244.

6. Marouani H, Rzaigui M and Al-Deyab S S, Acta Cryst., 2010, E66, o2613.

7. Stewart J J P, J Mol Model., 2008, 14, 499.

8. Møller C and Plesset M S, Phys Rev., 1934, 46, 618.

9. Foster J P and Weinhold F, J Am Chem Soc., 1980, 102, 7211.

10. Sheldrick G M, SHELXS97 and SHELXL97 Program for crystal structure solution and refinement, University of Gottingen Germany, 1997.

11. Farrugia L J, WinGX Program for crystallography Package, J Appl Cryst., 1999, 32, 837.

12. Farrugia L J, ORTEP-3 program for molecular drawing, J Appl Cryst, 1997, 30, 565.

13. Stewart J P, Stewart Computational Chemistry, Version 10.341W MOPAC2009. $<$ http://openmopac.net>.

14. Gaussian 03, Revision C. 01, Frisch M J, Trucks G W, Schlegel H B, Scuseria G E, Robb M A, Cheeseman J R, Montgomery Jr J A, Vreven T, Kudin K N, Burant J C, Millam J M, Iyengar S S, Tomasi J, Barone V, Mennucci B, Cossi M, Scalmani G, Rega N, Petersson G A, Nakatsuji H, Hada M, Ehara M, Toyota K, Fukuda R, Hasegawa J, Ishida M, Nakajima T, Honda Y, Kitao O, Nakai H, Klene M, Li X, Knox J E, Hratchian H P, Cross J B, Adamo C, Jaramillo J, Gomperts R, Stratmann R E, Yazyev O, Austin A J, Cammi R, Pomelli C, Ochterski J W, Ayala P Y, Morokuma K, Voth G A, Salvador P, Dannenberg J J, Zakrzewski V G, Dapprich S, Daniels A D, Strain M C, Farkas O, Malick D K, Rabuck A D, Raghavachari K, Foresman J B, Ortiz J V, Cui Q, Baboul A G, Clifford S, Cioslowski J, Stefanov B B, Liu G, Liashenko A, Piskorz P, Komaromi I, Martin R L, Fox D J, Keith T, Al-Laham M A, Peng C Y, Nanayakkara A, Challacombe M, Gill P M W, Johnson B, Chen W, 
Wong M W, Gonzalez C and Pople J A, Gaussian 03, Gaussian, Inc., Wallingford CT, 2004.

15. GaussView, in: Keith T, Millam J, Eppinnett K, Hovell W L and Gilliland R, (Ed.),Version 4.12 R Dennington, Second Ed., Semichem, Inc., Shawnee Mission, KS, 2003.

16. Bernstein J, David R E, Shimoni L and Chang N L, Angew Chem Int Ed Engl., 1995, 34, 1555.

17. Cremer D and Pople J A, J Am Chem Soc., 1975, 97, 1354.

18. Zouari F, Ben Salah A and Hovestreydt E R, Acta Cryst., 1995, C51, 1563.

19. Janiak J, J Chem Soc Dalton Trans., 2000, 3885.

20. Desiraju G R and Steiner T, The Weak Hydrogen Bond in Structural Chemistry and Biology, Oxford University Press, Oxford, 1999.

21. Stewart J J P, J Mol Model., 2007, 13,1173.

22. Köster A M, Leboeuf M, Salahub D A, in: Murray J S and Sen K (Eds.), Molecular Electrostatic Potentials: Concepts and Applications, Theoretical and Computational Chemistry, vol. 3, Elsevier, Amsterdam, 1996, pp. 105 (Chapter 2).

23. Guandalini L, Martini E, Martelli C, Romanelli M N and Varani K, Farmaco., 2005, 60(2), 99.

24. Lewis D F V, Loannides C and Parke D V, Xenobiotica., 1994, 24, 401.

25. Zhou Z and Parr R G, J Am Chem Soc., 1990, 112, 5720.

26. Fukui K, Yonezawa T and Shingu H, J Chem Phys., 1952, 20, 722.

27. Padmaja L, Ravikumar C, Sajan D, Hubert Joe I, Jayakumar V S, Pettit G R and Faurskov Neilsen O, J Raman Spectrosc., 2009,40, 419.

28. Ravikumar C, Hubert Joe I. and Jayakumar V S, Chem Phys Lett, 2008, 460, 552.

29. Süleymanoglu N, Ustabas R, Bingöl Alpaslan Y, Ünver Y, Turan M and Sancak K, $J$ Mol Struct., 2011, 989, 101. 


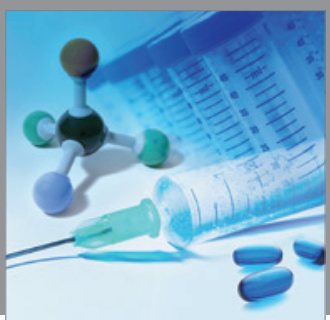

International Journal of

Medicinal Chemistry

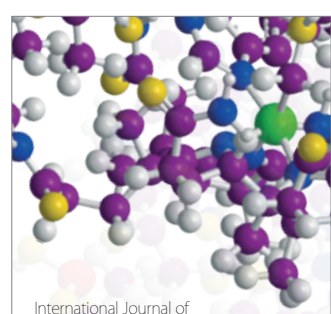

Carbohydrate Chemistry

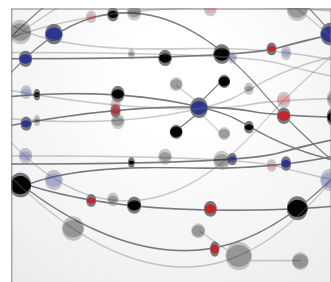

The Scientific World Journal
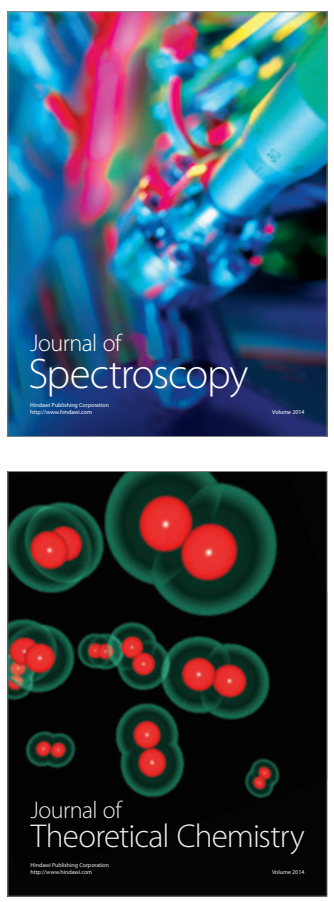
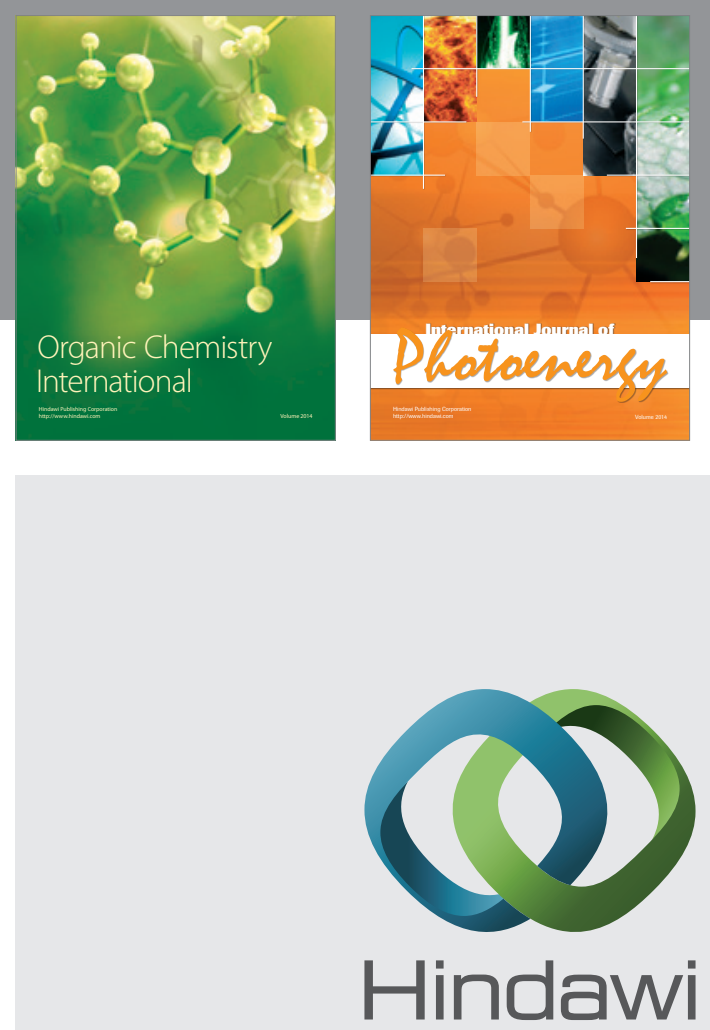

Submit your manuscripts at

http://www.hindawi.com
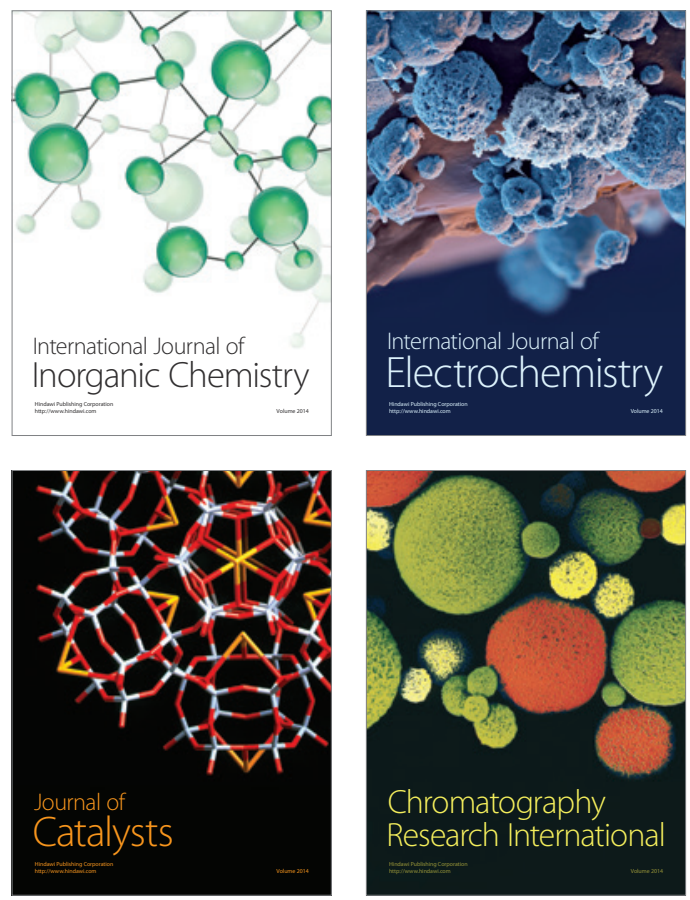
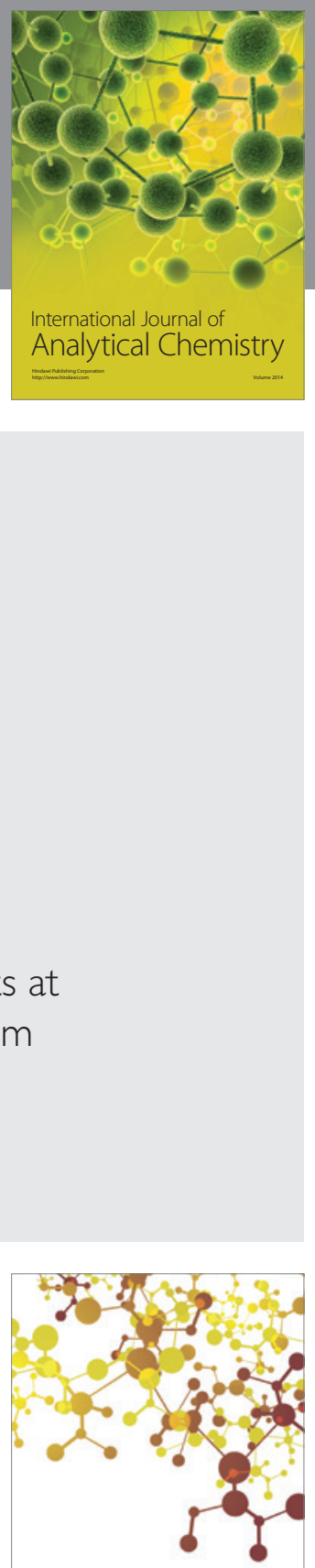

Journal of

Applied Chemistry
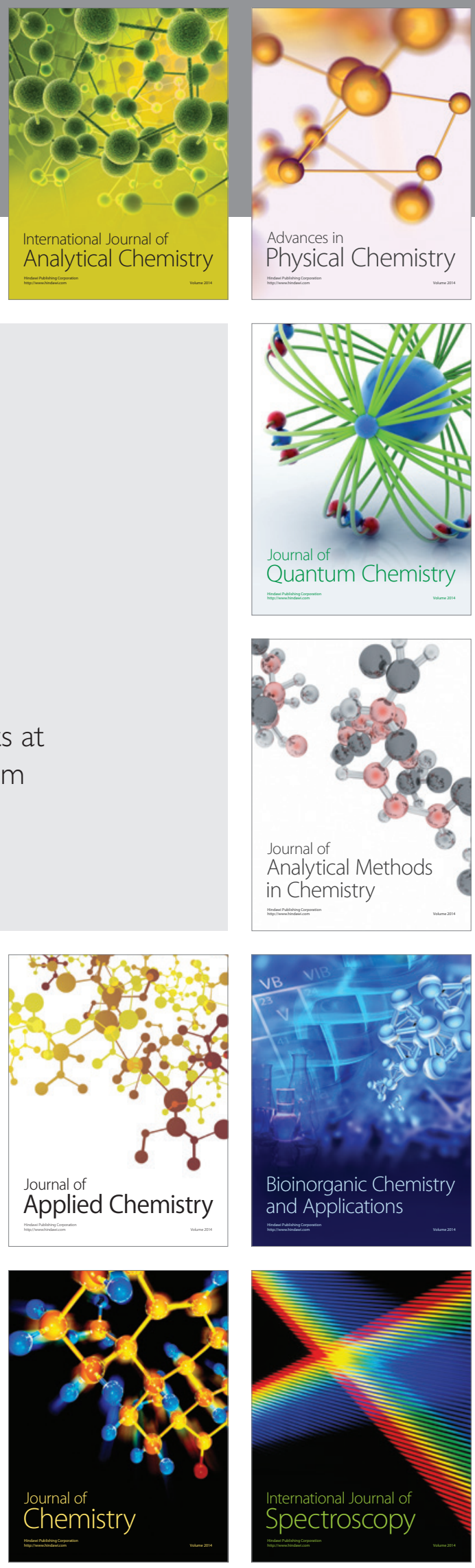